DOI: https://doi.org/10.47405/mjssh.v6i8.950

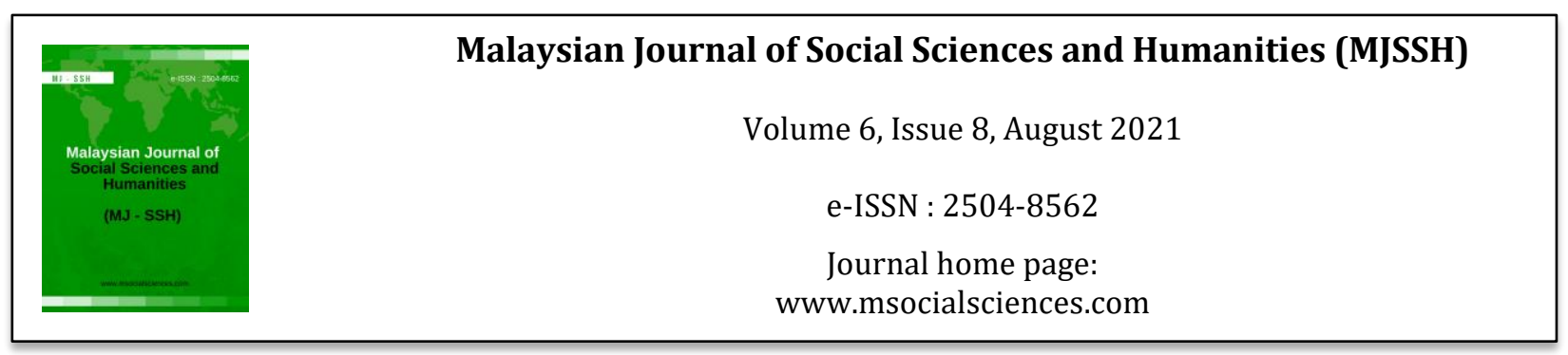

\title{
Kesahan dan Kebolehpercayaan Modul Pembelajaran Berasaskan Pengintergrasian Model Pembelajaran Inkuiri 5E dan Koperatif
}

\author{
Chai Wan Luen' ${ }^{1}$, Siew Nyet Moi @ Sopiah Abdullah' ${ }^{1}$, Lee Bih Nih'1 \\ 1Fakulti Psikologi dan Pendidikan, Universiti Malaysia Sabah (UMS) \\ Correspondence: Siew Nyet Moi @ Sopiah Abdullah (sopiah@ums.edu.my)
}

\begin{abstract}
Abstrak
Kajian ini dilaksanakan bagi menentukan kesahan dan kebolehpercayaan modul pembelajaran berasaskan pengintegrasian model pembelajaran inkuiri 5E dan koperatif (P5E-PK). Modul P5E-PK telah dibangunkan untuk memupuk Kemahiran Proses Sains Tahap Empat (KPST4) bagi mata pelajaran Sains Tingkatan Empat. Seramai dua orang panel pakar dan sembilan orang guru terlibat untuk menentukan kesahan kandungan modul berdasarkan lima kriteria iaitu i) rancangan pengajaran harian, ii) standard pembelajaran, iii) elemen KPS tahap empat, iv) pengintegrasian P5E-PK, dan v) pelaksanaan aktiviti. Selepas pelaksanaan modul, soal selidik berskala lima likert ditadbir ke atas 60 orang pelajar bagi mendapatkan penilaian terhadap kebolehlaksanaan dan kebolehgunaan aktviti dalam modul P5E-PK terhadap KPST4. Hasil penilaian pakar menunjukkan darjah persetujuan yang tinggi iaitu $93.27 \%$ dan modul yang dibangunkan memenuhi aspek yang digariskan dengan sedikit penambahbaikan. Penilaian guru terhadap modul menunjukkan nilai min keseluruhan 4.51 yang menunjukkan bahawa guru-guru bersetuju modul P5E-PK dapat diaplikasikan dalam PdPc. Didapati nilai Cronbach Alpha bagi penilaian subjek kajian terhadap kebolehlaksanaan aktiviti ialah 0.76. Ini menunjukkan aktiviti modul P5E-PK mempunyai ketekalan dalaman yang tinggi. Kebolehgunaan aktiviti memaparkan nilai min keseluruhan 4.20, menunjukkan bahawa subjek kajian bersetuju modul P5E-PK boleh digunakan untuk memupuk KPST4. Dapatan kajian ini menunjukkan bahawa modul P5E-PK mempunyai kesahan dan kebolehpercayaan yang tinggi dalam memupuk KPST4 dalam kalangan pelajar Tingkatan Empat.
\end{abstract}

Kata kunci: kesahan, kebolehpercayaan, kemahiran proses Sains Tahap Empat, modul pembelajaran

\section{Validity and Reliability of an Integrated 5E Inquiry and Cooperative Learning Models Based Learning Module}

\begin{abstract}
This study was conducted to determine the validity and reliability of a learning module based on the integration of 5E inquiry and cooperative learning models (P5E-PK). The P5E-PK module has been developed to cultivate the Level Four Science Process Skills (KPST4) for Form Four Science subjects. A total of two expert panels and nine teachers were involved to determine the validity of module content based on five criteria namely i) daily lesson plans, ii) learning standards, iii) KPS level four elements, iv) P5E-PK integration, and v) activity implementation. After the implementation of the module, a five-likert scale questionnaire was administered to 60 students to obtain an assessment of the feasibility and usability of the activities in the P5E-PK module on KPST4. The results of the expert evaluation showed a high degree of agreement of $93.27 \%$ and the modules developed met the aspects
\end{abstract}


outlined with slight improvements. Teachers' evaluation of the module showed an overall mean value of 4.51 which indicated that teachers agreed that the P5E-PK module could be applied in teaching and learning. It was found that the Cronbach Alpha value for the evaluation of the study subjects on the feasibility of the activity was 0.76 . This indicates that the activity of the P5E-PK module has high internal consistency. The applicability of the activity displayed an overall mean value of 4.20 , indicating that the study subjects agreed that the P5E-PK module could be used to foster KPST4. The findings of this study indicate that the P5E-PK module has high validity and reliability in fostering KPST4 among Form Four students.

Keywords: learning module, Level Four science process skills. reliability, validity

\section{Pengenalan}

Penguasaan kemahiran proses sains Tahap Empat (KPST4) adalah penting untuk pelajar mengaplikasikan pengetahuan sains, pengetahuan prosedur dan pengetahuan epistemik dalam mengemukakan soalan, menginterpretasikan data, menyelesaikan masalah, membuat perkaitan dan membuat keputusan dalam konteks kehidupan sebenar (Bahagian Pembangunan Kurikulum, 2018). Di samping itu, KPST4 membina kesedaran di kalangan pelajar bahawa penemuan melalui penyelidikan sains adalah usaha manusia menggunakan kemampuan akal untuk memahami fenomena alam ke arah mencapai kesejahteraan hidup (Rose et al., 2004).

KPST4 adalah terdiri daripada kemahiran mengenal pasti pemboleh ubah dimanipulasikan, pemboleh ubah bergerak balas, dan pemboleh ubah dimalarkan, membina hipotesis, membuat pemerhatian, membuat inferens, dan mendefinisikan secara operasi (Bahagian Pembangunan Kurikulum, 2018). KPST4 dinilai dalam Bahagian A Kertas 2 dalam subjek Sains secara bertulis semasa peperiksaan. Kertas 2 merangkumi tiga bahagian. Antara tiga bahagian dalam kertas 2, bahagian A yang banyak membantu pelajar untuk mendapat markah. Pelajar akan dapat menjawab soalan bahagian A jika mereka menguasai teknik menjawab kemahiran proses Sains. Bahagian A dalam kertas 2 hanya menyoal soalan tentang KPST4.

Beberapa kajian telah dijalankan mengenai tahap pencapaian KPS dalam kalangan pelajar di Malaysia (Chan, 1984; Tan \& Chin, 1992; Zurida, 1998). Dapatan-dapatan daripada kajian ini menunjukkan bahawa penguasaan KPS oleh pelajar Tingkatan Empat di Malaysia adalah tidak memuaskan dan pelajar didapati masih lemah dalam kemahiran proses sains. Dapatan kajian Yew (2000) juga mendapati bahawa tahap kemahiran proses sains pelajar secara keseluruhannya adalah sederhana $(44.18 \%)$ berdasarkan kajiannya yang melibatkan pelajar-pelajar Tingkatan Empat sebagai responden.

Hasil kajian Wun dan Sunita (2015) terhadap 150 orang pelajar Tingkatan Empat berkaitan dengan tahap penguasaan KPST4 menunjukkan bahawa tahap pencapaian pelajar secara keseluruhannya adalah sederhana dari segi mengenal pasti pemboleh ubah dimanipulasikan, pemboleh ubah bergerak balas, dan pemboleh ubah dimalarkan, membina hipotesis, dan membuat pemerhatian, manakala tahap lemah dari segi membuat inferens, dan mendefinisikan secara operasi. Dapatan kajian ini menunjukkan pencapaian pelajar bagi kemahiran membuat hipotesis berada pada tahap sederhana dengan peratus min sebanyak 54.37\%. Dapatan ini konsisten dengan dapatan kajian Nor Hasniza (2010) yang menunjukkan bahawa pencapaian pelajar bagi kemahiran membina hipotesis berada pada tahap sederhana dengan peratus min sebanyak $55 \%$.

Dapatan kajian Wun dan Sunita (2015) juga menunjukkan pencapaian pelajar bagi kemahiran mengawal pemboleh ubah berada pada tahap sederhana dengan peratus min sebanyak $52.72 \%$. Dapatan ini sama dengan dapatan kajian Zurida (1998), iaitu pencapaian pelajar bagi kemahiran mengawal pemboleh ubah berada pada tahap sederhana. Di samping itu kajian Wun dan Sunita juga menunjukkan pencapaian pelajar bagi kemahiran mendefinisikan secara operasi berada pada tahap sederhana dengan peratus min sebanyak $48.22 \%$. Dapatan ini selari dengan dapatan kajian Nor Hasniza (2010) di mana pencapaian pelajar bagi kemahiran mendefinisikan secara operasi berada pada 
tahap sederhana dengan peratus min sebanyak 55.67\%. Dapatan ini juga sama dengan dapatan kajian Burns et al. (1985) di mana pencapaian pelajar bagi kemahiran mendefinisikan secara operasi berada pada tahap sederhana dengan peratus min sebanyak $55.00 \%$.

Dapatan tersebut disokong oleh keputusan peperiksaan bagi Sains Tingkatan 4 di sebuah sekolah menengah di Sarawak (Rajah 1). GPMP subjek Sains didapati sangat rendah iaitu 7.75 yang menghampiri 9.00 .

Rajah 1: Keputusan Gred Purata Mata Pelajaran (GPMP) bagi peperiksaan subjek Sains Tingkatan 4

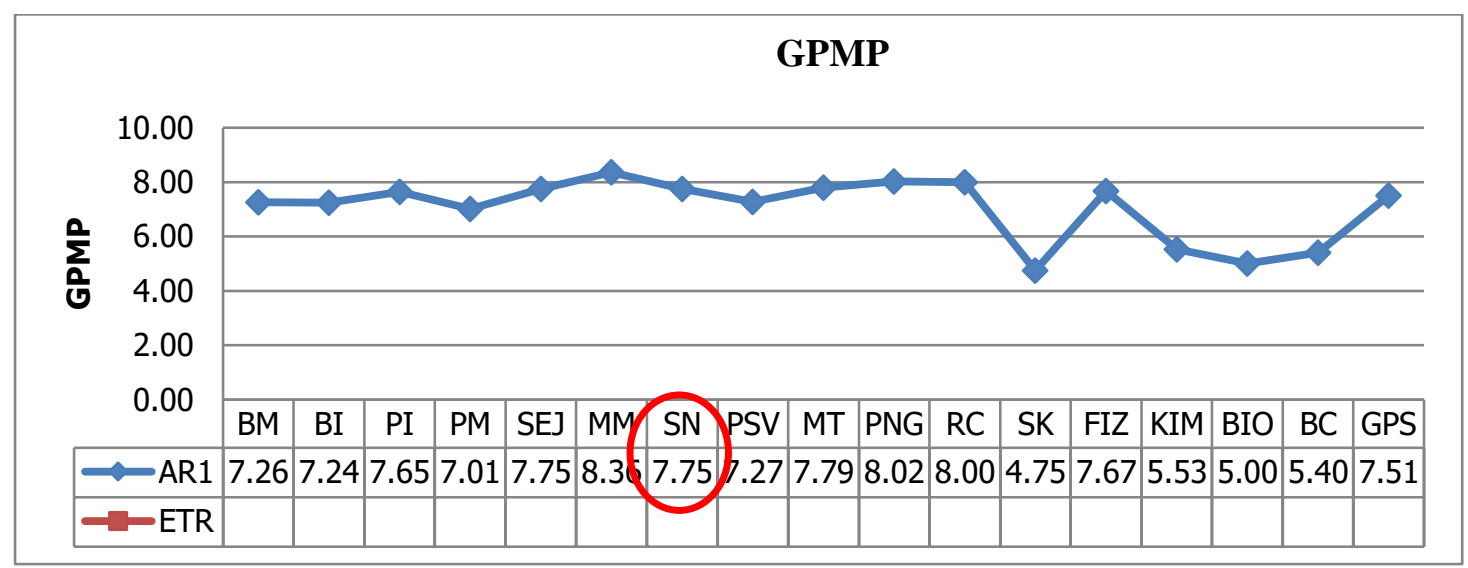

Sumber : SMK A, Sarawak (2019)

Rajah 2: Peratusan lulus bagi peperiksaan subjek Sains Tingkatan 4

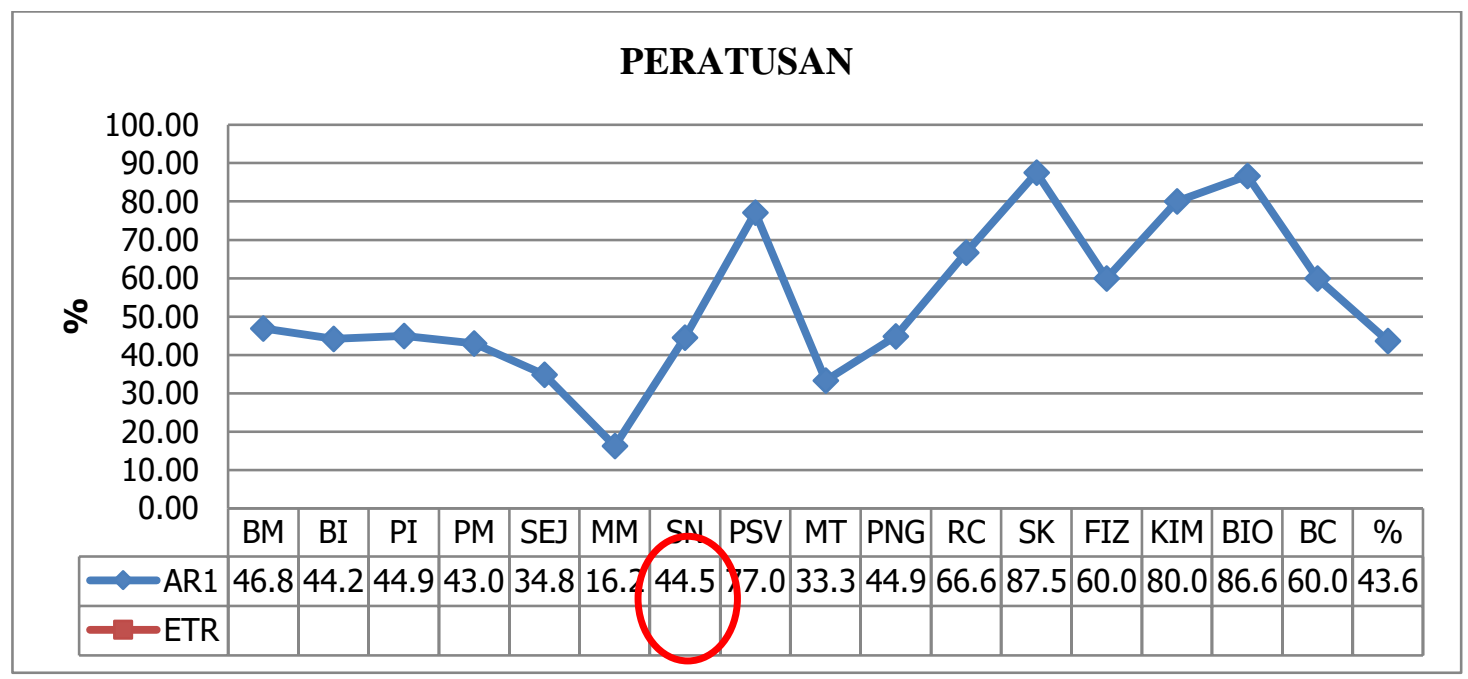

Sumber : SMK A, Sarawak (2019)

Hasil analisis menunjukkan bahawa hanya 44.5\% (72 orang) daripada 160 orang pelajar lulus dalam peperiksaan bagi subjek Sains Tingkatan 4 (Rajah 2). Berdasarkan analisis keputusan, didapati pelajar dari sebuah kelas adalah faktor utama ke atas pencapaian GPMP yang rendah kerana hanya seorang sahaja daripada jumlah 30 orang pelajar lulus dalam peperiksaan tersebut. Berdasarkan analisis item yang dibuat, didapati penyebab utama pelajar gagal dalam subjek Sains adalah disebabkan oleh pelajar tidak dapat menjawab dengan baik dalam soalan-soalan kertas 2 di bahagian A yang terdiri daripada KPST4. Hal ini dapat dilihat berdasarkan Rajah 3. 
DOI: https://doi.org/10.47405/mjssh.v6i8.950

Rajah 3 : Analisis item soalan kertas 2 peperiksaan Sains Tingkatan 4

\begin{tabular}{|c|c|c|c|c|c|c|c|c|c|c|c|c|}
\hline & \multicolumn{12}{|c|}{ SOALAN } \\
\hline & \multicolumn{4}{|c|}{ BAHAGIAN A } & \multicolumn{5}{|c|}{ BAHAGIAN B } & \multicolumn{3}{|c|}{ BAHAGIAN C } \\
\hline & 1 & 2 & 3 & 4 & 5 & 6 & 7 & 8 & 9 & 10 & 11 & 12 \\
\hline $\begin{array}{c}\text { MARKAH } \\
\text { PENUH } \\
\text { SETIAP } \\
\text { SOALAN }\end{array}$ & 5 & 5 & 5 & 5 & 6 & 6 & 6 & 6 & 6 & 10 & 10 & 10 \\
\hline $\begin{array}{l}\text { JUMLAH } \\
\text { MARKAH }\end{array}$ & 363 & 355 & 406 & 262 & 320 & 290 & 266 & 151 & 355 & 215 & 160 & 103 \\
\hline $\begin{array}{c}\text { PERATUS } \\
\text { YANG } \\
\text { DIKUASAI }\end{array}$ & 52.99 & 51.82 & 59.27 & 38.25 & 38.93 & 35.28 & 32.36 & 18.37 & 43.19 & 15.69 & 11.68 & 7.52 \\
\hline
\end{tabular}

Sumber : SMK A (2019)

Hasil dapatan ini jelas menunjukkan bahawa satu modul pembelajaran perlu dibangunkan bagi membantu guru membimbing pelajar dalam penguasaan KPST4. Maka, kajian tentang pembangunan modul adalah perlu dijalankan dalam usaha memupuk KPST4 bagi Sains Tingkatan Empat. Terdapat beberapa modul KPS yang pernah dibangunkan sebelum ini tetapi bukan bertujuan untuk memupuk KPST4. Sebagai contoh modul yang dibangunkan oleh Rose (2004) adalah bertujuan untuk memupuk KPS pelajar Tingkatan Dua iaitu tahap dua. Bahagian Pembangunan Kurikulum (BPK) telah membangunkan Modul KPS untuk murid Tahun Tiga (Bahagian Pembangunan Kurikulum, 2012) dan Tahun Empat (Bahagian Pembangunan Kurikulum, 2013). Modul ini digubal bagi membantu guru dalam merangka dan melaksanakan pengajaran dan pembelajaran sains bagi memupuk penguasaan kemahiran proses sains dalam kalangan murid. Perbincangan dan penglibatan aktif pelajar dalam kumpulan dapat menyumbang kepada proses pemahaman subjek yang dipelajari (Barron et al., 2013).

Hasil kajian Fazilah et al. (2016) mendapati bahawa kedua-dua kumpulan kajian yang menggunakan modul KPS dalam subjek Biologi menunjukkan peningkatan dalam min skor ujian pasca. Penggunaan modul mampu merangsang serta mengembangkan pemikiran kritis dan meta kognitif kalangan pelajar (Loyens et al., 2008). Modul KPS mampu memberi kesan positif terhadap pencapaian dalam mata pelajaran sains serta mampu mengurangkan miskonsepsi dalam kalangan pelajar (Akinoglu, 2008). Secara teorinya, kesan peningkatan pencapaian berlaku apabila pelajar menerima perubahan tingkah laku dengan penyepaduan strategi pengajaran yang khusus (Etherington, 2011). Topik pelajaran yang dipilih merupakan pengetahuan aras tinggi yang berbentuk "minds on" dan "hands on". Aplikasi kemahiran proses sains sama ada dalam pelaksanaan aktiviti mahupun penyelesaian masalah dalam modul yang disediakan memberi pelajar peluang untuk meneroka masalah diberi dalam kehidupan seharian pelajar. Pelajar perlu mengenal pasti masalah dan membuat kajian terperinci dari pelbagai sumber serta membina hipotesis berkaitan masalah yang diberi. Kekerapan dalam menyelesaikan masalah mampu memberi pengukuhan dalam kemahiran proses sains pelajar (Fazilah, 2016).

Sehubungan dengan itu, penyelidik membangunkan satu modul bagi memupuk KPST4 pelajar Tingkatan Empat dan seterusnya menguji kebolehpercayaan dan kesahannya.

\section{Kerangka Teoritikal Pembangunan Modul P5E-PK}

Modul P5E-PK yang dibangunkan adalah didasari oleh tiga teori utama iaitu Teori Pembelajaran Konstruktivisme, Teori Perkembangan Kognitif Jean Piaget (Piaget, 1964) dan Teori Perkembangan Kognitif Sosial Lev Vygotsky (Vygotsky, 1978). Modul yang dibangunkan juga didasari oleh Model Pembelajaran Inkuiri 5E (P5E) (Bybee, 2006) dan Model Pembelajaran Koperatif secara Penyiasatan Kumpulan (PK) (Kagan, 1992). Natijahnya, teori-teori dan model yang digunakan dijadikan sebagai asas dan panduan yang kukuh dalam membangunkan modul P5E-PK sesuai dengan tahap dan 
DOI: https://doi.org/10.47405/mjssh.v6i8.950

perkembangan pelajar Tingkatan Empat. Kerangka teoritikal dalam Pembangunan Modul dapat digambarkan seperti dalam Rajah 4.

Rajah 4: Kerangka Teoritikal pembangunan modul P5E-PK

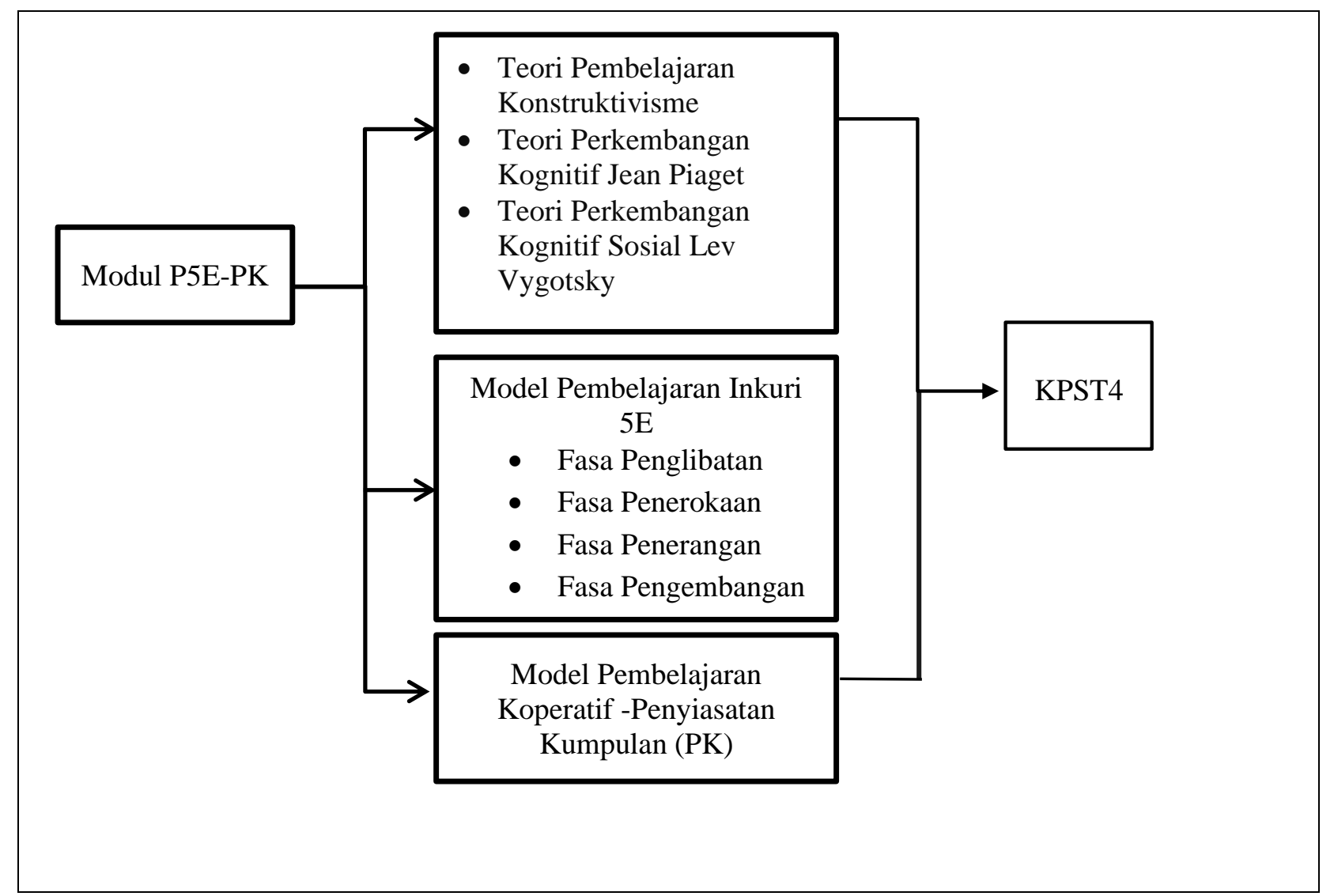

\section{Pengintegrasian Model Pembelajaran Berasaskan Inkuiri 5E dan Model Pembelajaran Koperatif (Penyiasatan Kumpulan)}

Penyelidik menggunakan pengintegrasian model pembelajaran berasaskan inkuiri kitaran 5E dan model pembelajaran koperatif (Penyiasatan Kumpulan) dalam membangunkan modul P5E-PK untuk memupuk Kemahiran Proses Sains Tahap Empat (Jadual 1). Model Pembelajaran 5E merujuk kepada lima fasa pembelajaran iaitu penglibatan (engagement), penerokaan (exploration), penerangan (explanation), pengembangan (elaboration) dan penilaian (evaluation) manakala penyiasatan kumpulan memerlukan pelajar untuk bekerja secara kumpulan meneroka dan memperoleh ilmu pengetahuan melalui fasa grouping, planning, investigation, organizing dan presenting.

Jadual 1: Pengintegrasian Model Pembelajaran Berasaskan Inkuiri 5E dan Model Pembelajaran Koperatif (Penyiasatan Kumpulan)

\begin{tabular}{cll}
\hline Langkah & $\begin{array}{l}\text { Model Pembelajaran Berasaskan } \\
\text { Inkuiri 5E }\end{array}$ & $\begin{array}{l}\text { Model Pembelajaran Koperatif } \\
\text { (Penyiasatan Kumpulan) }\end{array}$ \\
\hline 1. & $\begin{array}{l}\text { Penglibatan- Guru menarik } \\
\text { perhatian pelajar }\end{array}$ & $\begin{array}{l}\text { Grouping- Pelajar dibahagikan kepada } \\
\text { beberapa kumpulan. }\end{array}$ \\
2. & $\begin{array}{l}\text { Penerokaan- Ketua kumpulan } \\
\text { menjelaskan tugasan kepada ahli } \\
\text { kumpulan dan membuat }\end{array}$ & $\begin{array}{l}\text { Planning - Ketua kumpulan } \\
\text { mengagihkan tugasan dan berbincang } \\
\text { strategi untuk menjalankan penyiasatan. }\end{array}$ \\
\hline
\end{tabular}


DOI: https://doi.org/10.47405/mjssh.v6i8.950

perancangan untuk menjalankan penyiasatan.

3. Penerangan- Ahli yang mahir akan menerangkan dan membantu ahli yang lemah semasa menganalisis data

4. Pengembangan - Setiap kumpulan diberikan tugasan baru untuk dibincangkan
Investigation - Setiap ahli kumpulan terlibat secara aktif untuk menjalankan penyiasatan.

Organizing - Ahli kumpulan memainkan peranan masing-masing untuk menghasilkan bahan pembentangan Presenting - pelajar akan menerangkan hasil perbincangan semasa pembentangan.

Organizing - Ahli kumpulan memainkan peranan masing-masing untuk menghasilkan bahan bentangan Presenting - pelajar akan menerangkan hasil perbincangan semasa pembentangan.

5. Penilaian - pelajar untuk bertanya soalan dan membuat refleksi terhadap PdPc yang telah dijalankan di samping membuat pembetulan pada tugasan tadi.

Semasa langkah pertama, guru menggunakan pelbagai cara seperti menonton video, melihat gambar, atau memberikan situasi yang berkaitan dengan tajuk yang akan dipelajari untuk menarik perhatian pelajar. Ini menggalakkan pelajar memberikan respons dan melibatkan diri secara aktif. Kemudian, pelajar dibahagikan kepada beberapa kumpulan yang masing-masing terdiri daripada empat orang ahli. diberikan kepada setiap kumpulan selepas pembahagian kumpulan. Sebagai contoh, tugasan yang diberikan adalah dalam bentuk situasi iaitu dua budak yang berlainan jisim sedang bermain hayun. Berdasarkan situasi tersebut, pelajar dalam kumpulan perlu berbincang dan mengenal pasti pernyataan masalah yang perlu dikaji berkaitan hubungan jisim dengan inersia. Selepas itu, pelajar akan merancang satu penyiasatan untuk menjalankan penyiasatan ke atas pernyataan masalah yang telah dikemukakan. Sepanjang masa tersebut pelajar akan berbincang dan meneroka KPST4 yang telah disenaraikan.

Pada langkah kedua, ketua kumpulan mengagihkan dan menjelaskan tugasan kepada setiap ahli dalam kumpulan. Kemudian, pelajar berbincang dalam kumpulan dan merancang langkah-langkah dan strategi yang perlu digunakan untuk menjalankan penyiasatan bagi tugasan diberikan. Semasa perbincangan, pelajar akan mengenal pasti pemboleh ubah dimanipulasikan, pemboleh ubah bergerak balas, dan pemboleh ubah dimalarkan. Di samping itu, pelajar juga mempelajari dari ahli kumpulan yang lebih mahir tentang cara membuat hipotesis. Selepas perancangan, penyiasatan akan dijalankan dalam kumpulan dan semua ahli terlibat secara aktif. Pada masa yang sama, setiap ahli kumpulan akan membuat pemerhatian terhadap hasil eksperimen dan dapat menyatakan pemerhatian tersebut dengan betul. Pelajar juga akan dapat menganalisis data yang diperoleh berdasarkan hasil eksperimen dan perbincangan dalam kumpulan. Ahli kumpulan akan saling membantu bagi menghabiskan tugasan mereka. Maka, ahli yang mahir akan membimbing ahli yang lemah semasa menganalisis data seperti membuat inferens dan mendefinisikan secara operasi. Guru akan memantau dan membantu dari meja ke meja.

Seterusnya, pelajar akan membuat penerangan kepada ahli kumpulan semasa perbincangan dan sewaktu menghasilkan bahan pembentangan dalam fasa organizing. Kemudian, setiap kumpulan akan membentangkan hasil tugasan yang telah dihasilkan melalui pelbagai cara yang ditentukan oleh guru sama ada di depan kelas atau Gallery Walk dan sesi soal jawab akan berlangsung selepas itu. Pada masa ini, pelajar akan cuba mempelajari dan memantapkan pengetahuan melalui pembentangan daripada kumpulan lain tentang KPST4 yang telah dipelajari semasa dalam kumpulan tadi. Pelajar lain 
akan menyoal kepada kumpulan yang membentang dan kumpulan yang membentang akan menjawab soalan yang ditujukan secara terbuka.

Penambahbaikan terhadap hasil jawapan yang telah dibentangkan oleh kumpulan masing-masing akan dibuat. Seterusnya, setiap kumpulan akan diberikan situasi atau tugasan yang baru tentang KPST4 yang baru. Pelajar berbincang dan menjawab soalan KPST4 tersebut serta mempamerkan jawapan mereka. Pelajar akan memastikan mereka telah menguasai KPST4 dengan menjawab soalan yang diberi. Mereka akan meminta tunjuk ajar dari rakan-rakan yang lebih mahir. Akhir sekali, peringkat kelima memberikan peluang kepada pelajar untuk bertanya soalan dan membuat refleksi terhadap PdPc yang telah dijalankan di samping membuat pembetulan pada tugasan tadi.

Maka, diharap pembelajaran berasaskan model pembelajaran inkuiri kitaran 5E dan penyiasatan kumpulan dapat membantu pelajar untuk menguasai KPST4 dengan membina pengetahuan sendiri melalui penyiasatan dengan kerjasama dalam kumpulan. Kaedah pembelajaran ini juga membantu guru dari segi merancang PdPc yang berpusatkan pelajar serta sesuai bagi PAK21. Guru hanya bertindak sebagai fasilitator dan masa bercakap dikurangkan malah pelajar digalakkan untuk bercakap supaya dapat mempelajari pengetahuan melalui pengalaman sendiri. Tambahan pula, KPST4 ini mementingkan pengalaman melalui eksperimen yang dijalankan bermula dari langkah merancang sehingga menganalisis data.

\section{Objektif Kajian}

Objektif kajian ini adalah untuk menentukan kesahan dan kebolehpercayaan Modul pembelajaran berasaskan pengintegrasian model pembelajaran inkuiri 5E dan koperatif (P5E-PK).dalam memupuk KPST4.

\section{Metod Kajian}

\section{Subjek Kajian}

Subjek kajian adalah terdiri daripada pelajar Tingkatan Empat yang berumur 16 tahun serta menjalani kurikulum Kementerian Pendidikan Malaysia Sains Teras. Seramai 60 subjek kajian terlibat daripada sebuah sekolah menengah di daerah Lawas, Sarawak. Mengikut Cooper dan Schindler (2011), jumlah subjek kajian di antara 25 hingga 100 orang adalah mencukupi bagi penghasilan dapatan kajian yang tepat dan konsisten.

\section{Pembangunan Modul P5E-PK}

Sebanyak enam aktiviti disediakan dalam Modul P5E-PK. Kemahiran Proses Sains Tahap Empat ini berdasarkan Dokumen Standard Kurikulum dan Pentaksiran yang terkandung dalam Kurikulum Standard Sekolah Menengah Sains Tingkatan Empat dan Lima. Aktiviti tersebut melibatkan sesi mengeksperimen yang wajib dan paling utama untuk dijalankan yang melibatkan tajuk Sains Tingkatan Empat iaitu:

i. Kekuatan tulang yang padat dan tulang yang berongga.

ii. Kekerasan aloi

iii. Ketahanan kakisan aloi

iv. Kesan asid dan alkali ke atas lateks

v. Kekenyalan getah tervulkan dan getah asli

vi. Hubungan antara jisim dengan inersia

Pelajar akan dibahagi dalam kumpulan dan dikehendaki untuk menjalankan kesemua enam aktiviti tersebut dan menyelesaikan masalah yang disediakan berdasarkan model pembelajaran inkuiri 5E dan koperatif. Setiap aktiviti tersebut diperuntukkan masa sebanyak 120 minit. 
Sebagai contoh, Aktiviti 2 dalam modul ini adalah bertemakan penerokaan unsur dalam alam yang bertajuk Kimia Industri. Objektif aktiviti ini adalah mengkaji salah satu ciri aloi iaitu kekerasan. Pelajar diberikan tugasan untuk membandingkan kekerasan aloi dengan logam tulen. Pelajar dalam kumpulan hanya diberikan gambar dan sedikit penerangan. Mereka perlu berbincang bersama tentang cara dan prosedur untuk menjalankan penyiasatan kekerasan aloi. Semasa perancangan penyiasatan, mereka dikehendaki untuk melakarkan rajah bagi menunjukkan susunan bahan dan radas. Kemudian pelajar perlu mencatatkan pemerhatian mereka dalam bentuk jadual. Selepas penyiasatan, pelajar akan membuat analisis data dengan menjawab soalan KPST4 yang merangkumi membuat pemerhatian, membuat inferens, dan mendefinisikan secara operasi berdasarkan penyiasatan yang telah dijalankan dan akhirnya pelajar akan membentangkan jawapan mereka mengikut kumpulan.

Memandangkan aktiviti modul ini melibatkan penyiasatan saintifik, maka para pelajar diingatkan untuk mengikuti langkah-langkah penyiasatan saintifik dalam fasa Penerokaan seperti berikut: masukkan KPST4 diuji dalam setiap langkah seperti Rajah 5.

Rajah 5: Langkah-langkah dalam penyiasatan saintifik

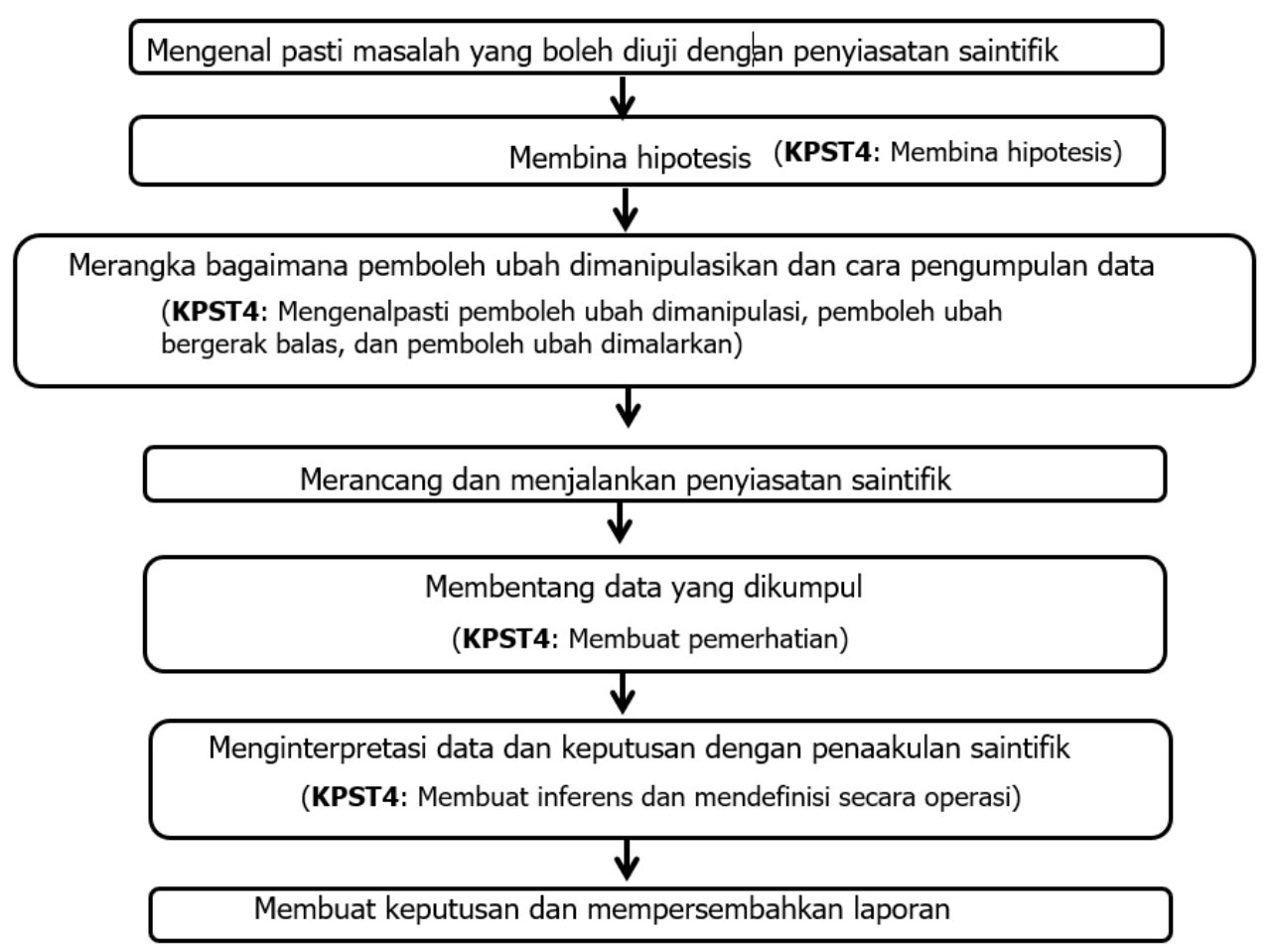

Sumber: Bahagian Pembangunan Kurikulum (2018)

\section{Pengumpulan Data}

Kebolehlaksanaan dan kebolehgunaan modul merupakan aspek yang perlu diberi penekanan dalam proses pembinaan modul. Kebolehlaksanaan sesuatu modul adalah ketika proses mencuba aktiviti modul tersebut dengan melihat maklum balas daripada peserta manakala kebolehgunaan modul adalah untuk membantu pelajar mencapai objektif modul yang telah dinyatakan (Jamaludin, 2016).

Modul P5E-PK telah diberikan kepada dua orang panel pakar yang bertujuan untuk menentukan kesahan kandungannya. Panel pakar dikehendaki membuat penilaian pada borang penilaian terhadap tujuh kriteria iaitu i) Rancangan Pengajaran Harian (RPH), ii) Standard Pembelajaran (SP), iii) Elemen pendekatan P5E-PK terhadap KPST4, iv) Pengintegrasian Model berasaskan Pembelajaran Inkuiri 5E dan Koperatif v) Pelaksanaan Aktiviti vi) Elemen KPS Tahap Empat Pelajar dan vii) Keseluruhan Modul. Panel pakar juga diminta membuat penilaian terhadap aktiviti-aktiviti yang dibangunkan dalam modul. Selain itu, satu soal selidik berskala lima likert ditadbir ke atas sembilan orang guru bagi 
mendapatkan maklum balas tentang elemen yang sama seperti dinilai oleh panel pakar. Selepas pelaksanaan modul, satu set soal selidik berkala lima likert ditadbir ke atas 60 orang pelajar Tingkatan Empat bagi mendapatkan penilaian terhadap pelaksanaan aktiviti dan kebolehgunaan aktiviti dalam memupuk KPS Tahap Empat.

\section{Dapatan Kajian}

\section{Kesahan Modul P5E-PK}

\section{Penilaian Pakar}

Jadual 2 menunjukkan dapatan daripada panel pakar terhadap kesahan keseluruhan kandungan modul P5E-PK mengikut aspek penilaian yang diberikan. Dapatan menunjukkan panel pakar $100 \%$ setuju dengan enam kriteria yang dikemukakan bagi penilaian keseluruhan kandungan modul P5E-PK.

Jadual 2: Dapatan Panel Kesahan keseluruhan Kandungan Modul P5E-PK

\begin{tabular}{|c|c|c|c|c|}
\hline \multirow[t]{2}{*}{ Bil } & \multirow[t]{2}{*}{ Kriteria } & \multicolumn{2}{|c|}{ Peratus (\%) } & \multirow{2}{*}{$\begin{array}{c}\text { Jumlah } \\
\text { Keseluruhan } \\
(\%)\end{array}$} \\
\hline & & Pakar A & Pakar B & \\
\hline 1. & Rancangan Pengajaran Harian & 100 & 100 & 100 \\
\hline 2. & Standard Pembelajaran & 100 & 100 & 100 \\
\hline 3 & $\begin{array}{l}\text { Elemen Pendekatan P5E-PK terhadap } \\
\text { KPST4 }\end{array}$ & 100 & 100 & 100 \\
\hline 4 & $\begin{array}{l}\text { Pengintegrasian Model Pembelajaran } \\
\text { berasaskan Inkuiri 5E dan Pembelajaran } \\
\text { Koperatif }\end{array}$ & 100 & 100 & 100 \\
\hline 5 & Pelaksanaan Aktiviti & 100 & 100 & 100 \\
\hline 6. & Elemen KPS Tahap Empat & 100 & 100 & 100 \\
\hline 7. & Keseluruhan kandungan Modul & 100 & 100 & 100 \\
\hline
\end{tabular}

Seterusnya, Jadual 3 menunjukkan peratus persetujuan daripada penilaian panel pakar mengikut aktiviti-aktiviti yang dibangunkan dalam modul. Maklum balas daripada kedua-dua pakar menunjukkan darjah persetujuan yang tinggi iaitu $93.27 \%$.

Jadual 3: Dapatan Kesahan Aktiviti Modul P5E-PK

\begin{tabular}{llcc}
\hline & \multicolumn{1}{c}{ Kriteria Penilaian } & \multicolumn{2}{c}{ Peratus (\%) persetujuan } \\
No & \multicolumn{1}{c}{ Pakar 1 } & Pakar 2 \\
\hline $\mathbf{1}$ & Pelaksanaan Aktiviti 1 & 98 & 98 \\
$\mathbf{2}$ & Pengintegrasian P5E-PK Aktiviti 1 & 98 & 99 \\
$\mathbf{3}$ & Pelaksanaan Aktiviti 2 & 98 & 99 \\
$\mathbf{4}$ & Pengintegrasian P5E-PK Aktiviti 2 & 98 & 100 \\
$\mathbf{5}$ & Pelaksanaan Aktiviti 3 & 99 & 98 \\
$\mathbf{6}$ & Pengintegrasian P5E-PK Aktiviti 3 & 99 & 100 \\
$\mathbf{7}$ & Pelaksanaan Aktiviti 4 & 98 & 100 \\
$\mathbf{8}$ & Pengintegrasian P5E-PK Aktiviti 4 & 100 & 100 \\
\hline
\end{tabular}


DOI: https://doi.org/10.47405/mjssh.v6i8.950

\begin{tabular}{llcc}
\hline $\mathbf{9}$ & Pelaksanaan Aktiviti 5 & 98 & 99 \\
$\mathbf{1 0}$ & Pengintegrasian P5E-PK Aktiviti 5 & 99 & 100 \\
$\mathbf{1 1}$ & Pelaksanaan Aktiviti 6 & 99 & 98 \\
$\mathbf{1 2}$ & Pengintegrasian P5E-PK Aktiviti 6 & 100 & 100 \\
$\mathbf{1 3}$ & Penilaian Keseluruhan aktiviti Modul & 99 & 98 \\
& Jumlah Keseluruhan & $\mathbf{9 3 . 0 6}$ & $\mathbf{9 3 . 4 7}$ \\
\hline
\end{tabular}

Secara keseluruhannya, para panel bersetuju bahawa modul yang dibangunkan ini memenuhi aspekaspek yang digariskan dengan hanya sedikit cadangan penambahbaikan yang perlu dibuat untuk memantapkan lagi kualiti kandungan Modul P5E-PK. Makluman cadangan penambahbaikan daripada panel penilai yang dilantik adalah dibentangkan seperti Jadual 4.

Jadual 4: Cadangan Penambahbaikan Modul Daripada Panel Penilai

\begin{tabular}{l}
\hline Aspek \\
\hline Rancangan Pengajaran \\
Harian \\
Standard \\
Pembelajaran \\
Elemen pendekatan \\
P5E-PK terhadap \\
KPST4 \\
Pengintegrasian \\
Model Pembelajaran \\
Berasaskan Inkuiri 5E \\
dan Koperatif \\
Pelaksanaan Aktiviti
\end{tabular}

Elemen KPS Tahap Empat Pelajar

Keseluruhan Modul

\section{Ulasan/Penambahbaikan}

Bilangan/ Isi padu bagi BBM perlu dinyatakan dengan jelas untuk persediaan awal oleh pembantu makmal $-$

Perkembangan Kognitif Sosial Lev Vygotsky boleh diterapkan untuk menyokong pendekatan P5E-PK

Soalan boleh disediakan untuk membimbing murid-murid mendefinisikan secara operasi dalam fasa penerangan

1. Set sampel jawapan untuk guru perlu disediakan.

2. Lembaran kerja murid berstruktur untuk bahagian prosedur perlu disediakan untuk membantu murid-murid tahap berpencapaian rendah.

3. Bilangan/isipadu bagi BBM perlu dinyatakan dengan jelas untuk persediaan awal oleh pembantu makmal.

4. Lembaran kerja untuk Fasa Pengembangan perlu diwujudkan bagi catatan murid-murid mengikut cadangan komunikasi yang berbeza.

Soalan hendaklah disediakan untuk membimbing murid-murid mendefinisi secara operasi dalam fasa penerangan

1. Tahap inkuiri sama ada inkuiri pengesahan, inkuiri berstruktur, inkuiri terbimbing atau inkuiri terbuka perlu diambil kira semasa pelaksanaan aktiviti modul ini.

2. Pelaksanaan perlu mengambil kira waktu pengajaran yang diperuntukkan di sekolah. Tidak semua sekolah mempunyai waktu anjal 90minit (3waktu) atau 120 minit (40 minit). Kemungkinan perlu mengambilkira pelaksanaan sesi1 (60 minit) dan sesi 2 (60 minit) pada hari yang berlainan bagi menyempurnakan sesuatu aktiviti.

3. Kegunaan modul ini perlu mempertimbangkan kegunaan yang lebih sesuai terhadap kumpulan murid-murid yang berpencapaian tinggi, berpencapaian sederhana atau berpencapaian rendah. 


\section{Penilaian Guru}

Jadual 5 menunjukkan min keseluruhan penilaian guru terhadap modul P5E-PK dari aspek elemen KPS Tahap Empat, pelaksanaan aktiviti, integrasi model pembelajaran berasaskan inkuiri 5E dan koperatif, dan keseluruhan modul. Nilai min yang diperoleh adalah nilai 4.51. Hasil ini menerangkan darjah persetujuan guru-guru adalah berada pada tahap yang tinggi bahawa modul P5E-PK ini sesuai untuk diaplikasikan di dalam kelas dalam memupuk KPS Tahap Empat dalam kalangan pelajar Tingkatan Empat Sains Teras.

Jadual 5: Penilaian Guru Terhadap Elemen KPS

\begin{tabular}{clc}
\hline No & Kriteria Penilaian & Nilai Min \\
\hline 1 & Elemen KPS Tahap Empat & 4.72 \\
2 & Pelaksanaan Aktiviti & 4.38 \\
3 & Integrasi Model Pembelajaran Berasaskan Inkuiri 5E & 4.45 \\
& Dan Koperatif & 4.50 \\
4 & Keseluruhan Modul & $\mathbf{4 . 5 1}$ \\
\hline
\end{tabular}

\section{Kebolehpercayaan Modul P5E-PK}

Jadual 5 menunjukkan dapatan penilaian kebolehlaksanaan aktiviti modul dan Jadual 6 menunjukkan kebolehgunaan aktiviti.

\section{Kebolehlaksanaan Aktiviti (Cronbach Alpha)}

Nilai Cronbach Alpha yang diperoleh bagi setiap aktiviti dalam modul adalah antara $.70-.82$ dengan nilai keseluruhan Cronbach Alpha modul P5E-PK ialah .76 seperti pada Jadual 4. Hal ini menunjukkan ketekalan dalaman aktiviti modul P5E-PK yang dibangunkan adalah tinggi.

Jadual 5: Penilaian Kebolehlaksanaan aktiviti dalam modul (N=60)

\begin{tabular}{|c|c|c|}
\hline Aktiviti & Tajuk dalam modul & Cronbach Alpha \\
\hline 1 & Kekuatan Tulang Berongga dan Tulang Padat & .70 \\
\hline 2 & Kekerasan Aloi & .75 \\
\hline 3 & Ketahanan Kakisan Aloi & .80 \\
\hline 4 & Kesan Asid dan Alkali ke atas Lateks & .73 \\
\hline 5 & Kekenyalan Getah Asli dan Getah Tervulkan & .78 \\
\hline \multirow[t]{2}{*}{6} & Inersia Dipengaruhi oleh Jisim & .82 \\
\hline & Jumlah & .76 \\
\hline
\end{tabular}

\section{Kebolehgunaan Aktiviti}

Jadual 6 membentangkan hasil penilaian kebolehgunaan aktiviti modul daripada skor min terendah hingga skor min tertinggi. Hasil penilaian kebolehgunaan aktiviti menunjukkan aktiviti modul mempunyai nilai skor min keseluruhan 4.20, menunjukkan modul mempunyai aktiviti yang kebolehgunaannya tinggi dalam memupuk KPS Tahap Empat Sains Tingkatan Empat. Menurut Inas, et al. (2015), skor min sama atau lebih daripada 3.50 dianggap sebagai boleh diterima, manakala di bawah 3.50 dianggap sebagai tahap yang tidak memuaskan dan penambahbaikan perlu dibuat terhadap modul. Tahap skor min antara 4.05 hingga 4.26 menunjukkan pelajar-pelajar Tingkatan 4 bersetuju modul P5E-PK boleh digunakan untuk memupuk KPS Tahap Empat dalam Sains Tingkatan Empat. 
Jadual 6: Penilaian Kebolehgunaan Aktiviti Pendekatan P5E-PK

\begin{tabular}{clc}
\hline No & \multicolumn{1}{c}{ Konstruk } & Nilai Min \\
\hline 1 & Elemen KPS Tahap Empat & 4.20 \\
2 & Pelaksanaan Aktiviti & 4.25 \\
3 & Integrasi Model Pembelajaran Berasaskan Inkuiri 5E Dan Koperatif & 4.20 \\
4 & Keseluruhan Modul & 4.15 \\
\hline \multicolumn{2}{c}{ Jumlah Min Keseluruhan } & $\mathbf{4 . 2 0}$ \\
\hline
\end{tabular}

\section{Perbincangan}

Kajian ini merupakan satu usaha untuk membangunkan modul pengintergrasian model pembelajaran berasaskan inkuiri 5E dan pembelajaran koperatif (penyiasatan kumpulan) (P5E-PK) dalam pembelajaran kemahiran proses sains Tahap Empat (KPST4), dan seterusnya menilai kebolehpercayaan dan kesahannya dalam kalangan pelajar Tingkatan Empat.

Secara keseluruhannya, modul ini didapati mempunyai kesahan yang tinggi untuk memupuk KPST4 iaitu kemahiran pengenalpastian pemboleh ubah dimanipulasikan, pemboleh ubah bergerak balas, dan pemboleh ubah dimalarkan, membina hipotesis, membuat pemerhatian, membuat inferens, dan mendefinisikan secara operasi. Panel pakar telah memberikan persetujuan $100 \%$ bagi kesahan kandungan modul P5E-PK berdasarkan kriteria yang telah ditetapkan. Di samping itu, pakar penilai dan guru-guru juga menunjukkan persetujuan yang tinggi bahawa modul P5E-PK memenuhi aspekaspek yang digariskan.

Pelajar Tingkatan Empat yang terlibat dalam kajian ini juga memberi penilaian yang positif dengan skor min yang tinggi bahawa modul P5E-PK boleh dipakai dan dilaksanakan serta dapat memupuk kemahiran mereka dari segi KPST4.

\section{Kesimpulan}

Kesahan dan kebolehpercayaan merupakan aspek terpenting dalam pembangunan sesuatu modul PdPc. Hasil daripada analisis kesahan dan kebolehpercayaan dapat membantu penyelidik dalam memastikan bahawa modul dapat dilaksanakan secara efektif dalam kajian sebenar. Kesimpulannya, kajian ini telah menunjukkan bahawa modul P5E-PK mempunyai kesahan dan kebolehpercayaan yang boleh diterima bagi mengukur KPS Tahap Empat.

\section{Rujukan}

Akinoglu, O. (2008). Assessment of the inquiry-based project application in Science Education upon Turkish Science Teachers' Perspectives. Education, 129(2), 202-215.

Bahagian Pembangunan Kurikulum. (2012). Kurikulum Standard Sekolah Rendah: Dokumen Standard Kurikulum dan Pentaksiran Sains Tahun 3. Kementerian Pelajaran Malaysia.

Bahagian Pembangunan Kurikulum. (2013). Kurikulum Standard Sekolah Rendah: Dokumen Standard Kurikulum dan Pentaksiran Sains Tahun 4. Kementerian Pelajaran Malaysia.

Bahagian Pembangunan Kurikulum. (2018). Kurikulum Standard Sekolah Menengah: Dokumen Standard Kurikulum dan Pentaksiran Sains Tingkatan 4 dan 5. Kementerian Pelajaran Malaysia.

Barron, L., Preston-Sabin, J., Kennedy, D. (2013). Problem-based learning for the pre-service teacher. Journal of the Southeastern Regional Association of Teacher Educators, 22(2), 39-45.

Bybee, R. W. (2009). The BSCS 5E instructional model and 21st century skills. National Academies Board on Science Education. Biological Sciences Curriculum Study.

https://sites.nationalacademies.org/cs/groups/dbassesite/documents/webpage/dbasse_073327.pdf 
Burns, J. C., Okey, J. R., \& Wise, K. C. (1985). Development of an integrated process skill test: TIPS II. Journal of Research in Science Teaching, 22, 169-177.

Chan, S. G. (1984). Acquisition of science process skills among Form 4 students in Kota Bahru. Unpublished Master Dissertation, University of Malaya.

Etherington, M. (2011). Investigative primary science: A problem-based learning approach. Australian Journal of Teacher Education, 36(9), 36-57. http://doi.org/10.14221/ajte.2011v36n9.2

Fazilah, R., Othman, T., \& Azraai, O. (2016). Aplikasi kemahiran proses sains dalam pembelajaran berasaskan masalah untuk mata pelajaran Biologi. Jurnal Kurikulum, Universiti Putra Malaysia.

Inas, S. J., Harry, B. S., Yugo, K. I., and Andika, Y. U. (2015). Usability evaluation of the student centered e-learning environment. International Review of Research in Open and Distributed Learning, 16(4), 62-82.

Jamaludin Ahmad. (2016). Modul Motivasi Diri. Ed. Ketiga. Dewan Bahasa dan Pustaka.

Kagan, S. (1992). Cooperative Learning: Resources for Teachers. San Juan Capistrano.

Loyens, S. M. M., Magda, J., \& Rikers, R. M. J. P. (2008). Self-directed learning in problem-based learning and its relationships with self-regulated learning. Educational Psychology Review, 20(4), 411-427. http://doi.org/10.1007/s10648-008-9082-7

Nor Hasniza, I. (2010). Tahap penguasaan kemahiran membuat hipotesis dan mendefinisi secara operasi di kalangan pelajar kimia Fakulti Pendidikan. Latihan ilmiah Ijazah Sarjana Muda yang tidak diterbitkan, Universiti Teknologi Malaysia, Skudai, Johor.

Piaget, J. 1964. Cognitive Development in Children: Development and Learning. Journal of research in Science Teaching, 2, 176-186.

Rose, A. B. R., Abdul R. J., Lilia H., \& Siti R. A. (2004). Pemupukan Kemahiran Proses Sains Di Kalangan Pelajar Tingkatan Dua Di Sekolah Bestari. Jurnal Teknologi. Universiti Teknologi Malaysia.

Tan, M. T., \& Chin, T. P. (1992). Satu kajian awal konsepsi kemahiran proses sains di kalangan guru sains PKPG 14 minggu di Maktab Perguruan Batu Lintang. Sarawak: Unit Sains, Maktab Perguruan Batu Lintang.

Wun, T. Y., \& Sunita, T. (2015). Tahap pencapaian kemahiran proses sains bersepadu dalam mata pelajaran Sains dalam kalangan pelajar tingkatan lima. J. Sci. Math. Lett. UPSI, 3, 7 - 14.

Yew, K. S. (2000). Tahap kefahaman kemahiran membuat inferens dan menganalisis kajian di kalangan pelajar-pelajar tingkatan empat. Latihan ilmiah Ijazah Sarjana Muda yang tidak diterbitkan, Universiti Teknologi Malaysia, Skudai, Johor.

Zurida Ismail. (1998). Penguasaan kemahiran proses sains di kalangan pelajar sekolah rendah dan menengah. Jurnal Kurikulum, 1 (1), 109-120.

Vygotsky, L.S. 1978. Mind in Society: The Development of Higher Psychological Processes. Cambridge, Harvard University Press. 